\title{
Patterns and paths towards privatisation in Ireland
}

\section{Craig Skerritt \& Maija Salokangas}

To cite this article: Craig Skerritt \& Maija Salokangas (2019): Patterns and paths towards privatisation in Ireland, Journal of Educational Administration and History, DOI: 10.1080/00220620.2019.1689104

To link to this article: https://doi.org/10.1080/00220620.2019.1689104

曲 Published online: 13 Nov 2019.

Submit your article to this journal $־$

Q View related articles $\sqsubset$

View Crossmark data $\circlearrowright$ 


\title{
Patterns and paths towards privatisation in Ireland
}

\author{
Craig Skerritt (iD ${ }^{a}$ and Maija Salokangas ${ }^{b}$ \\ ${ }^{a}$ Dublin City University, Dublin, Ireland; ${ }^{\text {}}$ Trinity College Dublin, Dublin, Ireland
}

\begin{abstract}
This paper discusses the various ways privatisation processes affect Irish education. Due to the long history of considerable church involvement, the notable absence of middle tiers of governance, and more recently, the embrace of neoliberal principles, in large part due to and for economic reasons, the Irish education system represents a fascinating example of a complex interplay between the public and private sectors. The conceptual and analytical tools provided by Cultural Political Economy are used in this paper to highlight why and how privatisation has unfolded and might yet unravel further in Irish education. These tools offer a useful lens through which to examine country-specific developments, whilst locating them in the global picture. Utilising the conceptualisations offered by Cultural Political Economy, this paper demonstrates how different forms of privatisation in Ireland have contributed to what can be described as a complex system of governance with strong private involvement.
\end{abstract}

\section{ARTICLE HISTORY}

Received 13 February 2019

Accepted 16 October 2019

\section{KEYWORDS}

Privatisation; school autonomy; governance; public education; Ireland

\section{Introduction}

New Public Management, a philosophical corpus of managerial ideas aimed at driving public sector reform in a range of policy areas (Verger and Curran 2014), is acknowledged by many scholars as having emerged in wealthy countries in the 1980s (see for example, Hood 1995; Wallis and Dollery 1999; Gruening 2001; Cole and Jones 2005; Noblet and Rodwell 2009; Paudel 2013; Steane, Dufour, and Gates 2015; Visser, Schouteten, and Dikkers 2019). Documented in the literature is the widespread supposition that this economic model would supposedly modernise the public sector and provide greater accountability and efficiency. Education policy, like other public services, has since undergone significant change in response to global economic, social and political drivers (Baxter 2017). The initial reforms that attempted to introduce marketisation and privatisation in the delivery of public services were later followed with intensified economic globalisation, and similar policies were adopted around the world as a way of monitoring and strengthening the competitiveness of education systems, as well as broader education reform packages that promoted decentralisation, school autonomy and the diversification of school provision (Verger, Fontdevila, and Parcerisa 2019a). Indeed, what Sahlberg $(2015,143)$ refers to as the Global Educational Reform Movement, or the GERM, has since become accepted as a 'new educational orthodoxy' within many recent education 
reforms throughout the world. This paper subscribes to Fuller and Stevenson's $(2019,1)$ assertion that this 'acronym-as-analogy' perfectly describes the phenomenon that Sahlberg identified as both spreading and destructive, behaving 'like an epidemic that spreads and infects education systems through a virus'. It is, as Sellar and Lingard $(2013,720)$ point out, a 'clever and telling acronym'. Accountability, standards, decentralisation and school autonomy are the main policy principles of the GERM (Verger, Parcerisa, and Fontdevila 2019b). For schools, this means becoming self-managing and independent, more efficient and accountable, and more competitive and business-like. Although privatisation is not explicitly acknowledged as a key component of the GERM, we share the view of others that it is one of its key (Carrasco and Gunter 2019) and essential features (Winchip, Stevenson, and Milner 2019). As Ball (2018) points out, education reform is now in effect a marketplace of business opportunities and commercial solutions.

How privatisation is understood in this paper is two-fold. It refers to both the use of non-state actors, sometimes for profit, in the provision of public services, and to state services behaving like private sector organisations. We therefore recognise privatisation as being polymorphic as opposed to monolithic (Verger, Fontdevila, and Zancajo 2017) in that privatisation processes

have not in practice responded to a single path ... privatisation has typically manifested itself in the constitution of hybrid education systems in which the public and the private sectors interact and distribute responsibilities in a complex and often contradictory manner. (Maroy in Verger, Moschetti, and Fontdevila 2018, 133)

Ball and Youdell (2007, 8-9), for example, refer to two types of privatisation: 'exogenous' privatisation, the opening up of public education services to private sector participation on a for-profit basis; and 'endogenous' privatisation, which involves importing ideas, techniques and practices from the private sector to make the public sector more businesslike. Similarly, Courtney $(2015,214-215)$ distinguishes privatisation, 'the private-sector appropriation of public assets', from corporatisation, the reconstitution of 'non-economic fields and relations as having the goals, practices, motivations and instincts of the private sector'. Our concern with privatisation, exogenous or endogenous, or even corporatisation, is that it changes the ethos, focus and purpose of education, serving private as opposed to public interests - and especially if profits are sought.

Several authors have now referred to the recent move towards school autonomy in Ireland (see Coolahan et al. 2017; Salokangas and Ainscow 2017; Carr and Beckett 2018; Skerritt 2019a). School autonomy involves devolving greater freedom and independence to individual schools, enabling them to manage their organisation (e.g. in terms of finances, staffing and the curriculum) in response to their own local needs. However, evidence from countries that have promoted school autonomy demonstrates that the extent to which local decision-making capacity actually increases as a result of such reforms varies (Salokangas and Chapman 2014; Kauko and Salokangas 2015; Salokangas and Ainscow 2017), and given the strong market principles that underpin the movement, school autonomy could be considered a way of, to some degree, privatising Irish schools (Skerritt 2019b) and/or making them more business-like (Skerritt 2019c). Increased school autonomy might involve using private actors to provide what has traditionally been the service of the state, but at the very least it would involve schools behaving like private-sector corporations - a form of corporatisation or an endogenous type of 
privatisation. For example, drawing on the literature on autonomous schools from around the world, Holloway and Keddie $(2018,3)$ note how marketing these schools and running them like businesses has become normal and common practice. Elaborating further, they point to the research in the United States, the United Kingdom, and Australia, which demonstrates how

'autonomy' has re-positioned public schools as competitive organisations that need to market their 'brand' accordingly and manage themselves in entrepreneurial ways. This rendering of public schools as market entities has ushered in a suite of business-like interests, logics and private investments (Burch 2009; Verger, Fontdevila, and Zancajo 2017).

This article discusses the various ways privatisation processes affect Irish education. Due to the long history of considerable church involvement, the notable absence of middle tiers of governance, and more recently the embrace of neoliberal principles in education policy, the Irish education system is a fascinating example of the complex interplay between the public and private sectors in education provision, the main private interest being the Catholic Church or what we often refer to simply as 'the church', while a more corporate tone is now also becoming embedded in the education system. Cultural Political Economy (CPE) has gained traction in education in recent years (see for example Robertson and Dale 2015; Verger, Fontdevila, and Zancajo 2016; Higgins and Novelli 2018), and this article specifically builds on Verger, Fontdevila, and Zancajo's (2017) use of Jessop's (2010) CPE approach. CPE promotes a critical understanding of the cultural embedding of social, economic and political transformations and will be used in this paper to highlight why and how privatisation has unfolded in Irish education, and how it could unravel further. It offers a useful lens through which to examine countryspecific developments, whilst locating them in the global picture. Utilising the conceptualisations offered by CPE, we will demonstrate how different forms of privatisation have contributed to what can be described as a complex system of governance with strong historical and more recent private involvement.

\section{Conceptual and analytical framework}

CPE offers us a way of understanding both why and how education privatisation unfolds in different settings. CPE, it is argued, provides us with a 'useful conceptual and analytical framework to study educational privatisation as a process of profound institutional transformation' (Verger, Fontdevila, and Zancajo 2017, 759). It is an analytical approach that accentuates how different actors interact in the production of pro-privatisation reforms through the evolutionary mechanisms of variation (the contingent emergence of new practices), selection (the subsequent privileging of these practices) and retention (the institutionalisation and inclusion of these policies into regulatory frameworks - this usually involves governments having to engage in political and discursive struggles and having to face opposition from teachers' unions and other bodies). Through a systematic literature review, Verger, Fontdevila, and Zancajo (2017) identified six different patterns and paths towards privatisation:

- Privatisation as a part of state structural reform: privatisation occurs via a deeply ideological and structural reform under neoliberal market principles. 
- Scaling up privatisation: privatisation takes place through the accumulation of gradual changes (frequently on a subnational level), which end up altering the public education system in a significant, but not necessarily linear, way. Often, market-driven solutions in education (school choice policies in particular) become conflated with principles such as equity or equal opportunities.

- The Nordic path towards educational privatisation: privatisation emerges in social democratic welfare states where there has traditionally been little private involvement.

- Historical public-private partnerships: privatisation is already embedded in some countries through a tradition of religious schooling that strongly conditioned the design of the education system before the emergence of neoliberalism. Here, these public-private partnerships can be explained by the combination of the historical role and the significant presence of religious institutions in education and the effective pressures these institutions exerted to play a central role in national education.

- The expansion of low-fee private schooling in low-income countries: privatisation happens not because governments are explicitly promoting it but because states are rather passive or unable to address new demands in education.

- Privatisation by way of catastrophe: privatisation is caused by an emergency or catastrophic situation, such as natural disasters or violent conflicts. Here, pro-market policies that would have experienced a far more limited advancement under different circumstances are more readily adopted. The need for a transparent and democratic debate is more easily side-lined in these contexts as the sense of urgency that prevails facilitates the advancement and retention of unpopular reforms.

Three of these patterns and paths in particular, 'historical public-private partnerships', 'scaling up privatisation', and 'privatisation by way of catastrophe', are helpful in examining the Irish case and dominate the discussion that follows. By 'historical public-private partnerships' Verger, Fontdevila, and Zancajo (2017) mean public-private partnerships that emerged before the global neoliberal policy turn, referring specifically to arrangements between religious institutions and the state and the ways in which education is organised and governed. This resonates strongly with the Irish education system, where religious patronage plays an important role in school governance. However, more recent forms of privatisation have also emerged in Ireland, which, to some extent, can be described in line with Verger, Fontdevila, and Zancajo's (2017) concepts of 'scaling up privatisation' and 'privatisation by way of catastrophe'. In using these three paths to explain the Irish case, we support the contention that elements from more than one path have converged in some countries (Verger, Fontdevila, and Zancajo 2016, 181; Verger, Fontdevila, and Zancajo 2017, 778-779; Verger, Moschetti, and Fontdevila 2018, 146).

\section{Patterns and paths towards privatisation in Ireland}

\section{Historical public-private partnerships}

In Ireland, the prevalence of much of the private sector involvement in education dates back to a time long before the contemporary wave of global education and pro-privatisation reforms started to take shape. The funding of nationwide post-primary education has 
its origins in the 1878 Intermediate Education Act, which set up payments to any school provider in a payment-by-results scheme. This meant that money could be funnelled into different types of schools as long as the schools presented candidates for examination. The scheme was in effect until 1924, essentially allowing religious education to prosper without making it look like the government was actually paying religious orders to provide an education system. The current Irish system is effectively an extension of this principle (Akenson 2012; Flanagan 1984). The historical public-private partnerships in Irish education (mainly with the Catholic Church) mean that publicly funded education remains to a great extent run by private providers who adhere to public regulations in terms of, for example, the curriculum, teachers' pay and conditions and admission procedures. Indeed, a distinctive feature of the Irish education system is the level of church involvement and control (Patrick 2005). Compared to the structures in other European countries where churches were losing ground to public initiative, Ireland's education system was distinctive by the twentieth century:

In other states where the churches rejected public education, the main price of rejection was the creation out of church funds of an alternative autonomous system; in Ireland the churches had secured a system which was acceptable to and controlled by them, but was funded mainly by the state. (Ó Buachalla 1985, 352)

There is ample evidence to suggest that following Irish independence in 1922 both the Catholic Church and the Protestant Church moved quickly to consolidate their dominant position in their respective educational provenances (Murphy 2008). The Catholic Church, however, has been the most predominant, with Ireland being a largely Catholic country. From 1922 onwards, Irish politicians and officials deferred extensively to the Catholic Bishops in formulating education policy, with the Catholic Church occupying a uniquely powerful position within the education system for over a generation (Walsh 2008). The Constitution ratified in 1937 instructed that the state 'shall respect and honour religion' (McCormack et al. 2019) and defined the education system as stateaided rather than state-provided (Fleming and Harford 2014) - an excellent arrangement for the Catholic Church. The decades following Irish independence were the heyday of the church in the new country and 'there was a priest, nun and brother in every corner of society' (O'Donoghue and Harford 2011, 325). Church control over education was absolute and was ensured through the vesting of local-level management control in parish priests at primary level, and through clerical institutional control and the presence of a strong teaching force of priests, brothers and nuns at post-primary level (Fleming and Harford 2014).

It was from the 1960s onwards that the church's control over Irish education began to weaken. Global players such as the World Bank, the European Union and the Organisation for Economic Co-operation and Development (OECD) became influential in Irish education policy alongside the religious expertise that had been informing policy goals (MacVeigh 2012), and a paradigm shift in education policy resulted in the significant democratisation of education, especially at post-primary level with the introduction of free education (Fleming and Harford 2014). Subsequently, the traditional restrictions on vocational education were removed, a comprehensive curriculum was established and vocational schools were brought within the ambit of a more integrated postprimary system, which then saw the further creation of community schools that were 
designed to deliver a comprehensive curriculum, incorporating both academic and vocational subjects (Walsh 2008). However, despite a number of attempts to establish a middle tier of administration between the Department of Education and Skills (DES) and individual schools over the last forty years, a striking feature of the Irish school system has been the lack of such a resource (Coolahan et al. 2017). With the exception of 36 percent of post-primary schools which now operate under the public management of one of sixteen regional Education and Training Boards (Liddy, O'Flaherty, and McCormack 2019) herein referred to as ETBs,

The meso level in Irish education has no local council intermediation between the national government policy direction and the schools and BOMs (Boards of Management) and Trusts that provide governance oversight of individual schools (King et al. 2019, 85).

Both Walshe (1999) and Fleming (2016) have detailed the history of these attempts over the twentieth century, and how on many occasions the Catholic Church was far from supportive of regionalisation. Nonetheless, by the 1990s the traditional power base of the Catholic Church was being re-negotiated and was reduced from the role of 'principal' actor to 'major' actor on the educational stage (OECD in Harford 2010). In addition to major scandals relating to the physical and sexual abuse of young people, the role of the church has continued to gradually decline in Irish society due to changing attitudes towards religion and religious practices, and an increased urge to overhaul the education system dominated by religious congregations (Faas, Darmody, and Sokolowska 2016).

To date, the churches, and the Catholic Church in particular, still retain a strong grip on the management of Irish schools. For example, more than 90 percent of primary schools and just under 50 percent of post-primary schools are classified as Catholic (Byrne and Devine 2018). In relation to post-primary level education, it is divided into a hierarchy of four main strata, as outlined by Coolahan et al. (2017, 115-116):

Fee-paying voluntary schools are at the 'top', followed by non-fee-paying voluntary secondary schools, then community and comprehensive schools and lastly the schools in what was the vocational education sector, now the Education and Training Board (ETB) sector.

The voluntary secondary schools are denominational and are privately owned and managed, typically by the Catholic Church, while community schools operate under the joint trusteeship of the ETB, a religious order and/or the Bishop or another nominated person, and comprehensive schools operate under the trusteeship of religious denominations. The ETB schools are publicly managed and were intended to be secular, but they are mainly managed by people who belong to the Catholic faith and cater to a predominantly Catholic student population. Therefore, in many ways they are a place where a Catholic ethos and Catholic school practices are a part of school life (Stapleton 2018). However, in addition to this, a charity body has been a patron of multi-denominational 'Educate Together' schools since 1978 (Faas, Smith, and Darmody 2018). Educate Together, a limited non-profit company (Rougier and Honohan 2015), is rapidly growing and represents a new departure in Irish education provision (Stapleton 2018). It currently operates 84 primary schools and 13 post-primary schools with more due to open in the near future. Educate Together schools seek to

ensure that parents have the choice of an education based on the inclusive intercultural values of respect for difference and justice and equality for all ... in an inclusive, democratic, co- 
educational setting that is committed to enabling and supporting each child to achieve their full potential while at the same time preparing them to become caring and active members of a culturally diverse society. (Educate Together in O'Flaherty et al. 2018, 324)

Thus, faith formation classes do not take place in these schools during the official school day (Sai 2018 ) and the emphasis is placed on learning about other religions rather than promoting one specific faith (Darmody and Smyth 2018).

With the exception of Educate Together schools, there is still strong church involvement in Irish schools. The Catholic Church has secured a strong role in most voluntary secondary schools, community and comprehensive schools and ETB schools:

Post-Primary schooling in Ireland could be described as a Church/State co-operative with the Church, or Church representatives, having a dominant role in the day to day management of the vast majority of schools. (Stapleton 2018, 11)

Thus, the Irish education system can be defined as a complex one in that most schools are privately owned and managed but state-funded. As Rougier and Honohan $(2015,73)$ explain:

The structure of the education system in the Republic of Ireland is unique among European countries: since the foundation of the state, almost all schools have been religious; $96 \%$ of primary schools, and a large proportion of secondary schools, are still denominational. The financing and administration of the education system are highly centralised in the Department of Education, including curricula; regulations for the recognition, management, resourcing, and staffing of schools; and negotiation of teachers' salaries. Yet, the provision and management of education are almost entirely devolved to other, largely private, bodies, so that there is virtually no strictly public state education in Ireland. The typical Irish school is neither strictly public, nor strictly private, but a hybrid.

\section{Scaling up privatisation}

Stemming from the paradigm shift in the 1960s, Irish education has come to be guided more and more by economics. Since the late 1990s, Irish public policy-making has been driven by neoliberal assumptions regarding the supremacy of the market (Lynch and Moran 2006), and since the millennium, Mooney Simmie $(2012,506)$ reports a 'changing tune of neoliberalism being played from soft to medium to loud' in Irish education. This is perhaps unsurprising given the recessionary economic climate in Ireland (Holland, Lorenzi, and Hall 2016) in recent years that has seen the country go from having one of the highest economic growth rates in the world to one of severe economic contraction (Drudy 2009). When the country was plunged into times of economic hardship, the President invited the public to engage with the discourse that makes the connection between the economy, society and state (Mooney Simmie 2012), and similar stances were taken by both the Minister for Education and Skills (see Quinn 2012) and the Chief Inspector of the DES (see Hislop 2012). As such, market reform initiatives have been supported across party lines, and they have frequently been associated with equity goals such as equal opportunities.

Perhaps the starkest examples of amplified privatisation are the profit-making companies which have become an integral part of Irish education. In addition to two providers of teacher preparation in Montessori education (O'Donoghue, Harford, and O'Doherty 2017), an online provider of teacher preparation in both primary and post-primary 
education has been firmly established. Hibernia College, a private (Houtsonen et al. 2010; Conway 2013; Furlong 2013), for-profit (Lynch 2012; O’Donoghue, Harford, and O’Doherty 2017) 'commercial provider ... (which receives no State aid) ... has become the largest provider of newly qualified primary teachers in the State' (Teaching Council in O'Doherty and Harford 2018, 661). A considerable proportion of graduating teachers, at both primary and post-primary levels, have chosen this route, and a lack of regulation of student numbers has resulted in, in some instances, a considerable oversupply of teachers. However, in addition to teacher supply issues, another challenge, and perhaps more worryingly, is the potential impact on the culture of teaching in Ireland:

It is arguable ... that with the advent of online, market-driven approaches to teacher preparation and continuing professional development, where education is promoted as being a private effort leading to individual good, the inherited and previously accepted culture of teaching as a collaborative and shared engagement may be undermined. (O'Donoghue, Harford, and O’Doherty 2017, 225)

Another example of relatively recent private for-profit entries that have become big players in the Irish education landscape are the 'grind schools', or private tuition centres, for school students, especially those from middle-class backgrounds (Sugrue 2006; Smyth 2008 , 2009). While some parents send their children to private tuition centres on a fulltime basis, another common trend is for students to attend these centres outside of their normal school hours, namely, during the evening, on weekends, and during school holidays. In any case, here in particular we can see how private actors are providing what has traditionally been state services, with greater trust being placed in them than in public sector professionals (Jessop 2007).

While recent decades have proven to be fertile ground for new forms of privatisation of Irish education, proposals for increased school autonomy, based on an ideology closely associated with school vouchers and English academies have been repeatedly put forward in Ireland, most notably through the publication of a research paper and a consultation paper, both of which are aptly entitled 'Advancing school autonomy in the Irish school system' (DES 2015a, 2015b). It is worth noting however, that 'advancing school autonomy in the Irish school system' was not received without criticism. While concerns have started to appear in the literature (see Carr and Beckett 2018; Skerritt 2019b, 2019c, 2019d), the DES website (see www.education.ie) now also provides the views submitted from interested parties 'on the issue of school autonomy' as part of the consultation. Of the 54 submitted responses, most are overwhelmingly negative. However, since this consultation many policy papers continue to frequently reference goals and objectives such as increasing the autonomy of schools, and particularly disadvantaged schools (see for example DES 2016, 2017; Government of Ireland 2018). Designated disadvantaged schools in Ireland are known as DEIS schools - 'DEIS' standing for Delivering Equality of Opportunity in Schools - and this agenda is indicative not only that the education system is moving towards a more laissez-faire approach, but also that it is associating market principles with equity and equal opportunities.

Given the declining role of the Catholic Church, the rise of neoliberal market principles, the drive towards establishing some form of self-managing schools in Ireland and the relationship between school autonomy and privatisation in many international contexts, it is very plausible that it is the intention of policy-makers in Ireland to extend the 
current private market beyond tuition centres and teacher education providers to the school system. For example, it was previously reported in the national media that the success and expansion of Hibernia College was 'being closely monitored at the Department of Education, where talk of a more privatised education system is moving up the agenda' (The Irish Times 2011). There is no reason to assume that this move has ceased.

\section{Privatisation by way of catastrophe}

While pro-privatisation reforms in Ireland cannot be attributed to any natural disasters or violent conflicts, a perceived catastrophe did occur via the 'bad news' (Conway and Murphy 2013) stemming from the OECD's 2009 Programme for International Student Assessment (PISA). Through PISA, the OECD measures the academic performances of students in different countries and publicly ranks countries based on these calculations. These measures are now accepted as criteria of good educational performance (Sahlberg 2011) and countries compete with one another in these assessments as a means of demonstrating global competitiveness. Thus, the OECD is now a major governing body in education and its global influence in education is symbolic of how education is coming to be used as a catalyst for economic growth by governments around the world. Ireland was certainly one of the countries that experienced the 'PISA shock' that Verger and Parcerisa $(2019,149)$ refer to. The impact the 2008 recession had on Ireland was 'especially severe, touching all aspects of social policy and practice, including education' (Hall and Horgan 2015, 175), and in a country where education is such a highly valued entity (see for example Drudy and Lynch 1993; Harford 2010; Dolan 2012: Canny and Hamilton 2018), a significant drop in the PISA standings while the country was suffering from a severe economic disaster formed the basis of a catastrophe in education. As Kitching (2014, 111) recounts, the PISA results 'released in the grip of severe austerity measures in 2010, became part of a mediated panic over teaching and learning standards, which were repeatedly, casually related to future national economic recovery'. Writing more recently, Murphy (2019) similarly refers to the PISA 'shock' at the time raising public concern about the fall in student attainment, and how it fed into the political and public appetite for increased transparency and accountability. Drawing on comments from both the Chief Inspector of the DES and the CEO of the National Council for Curriculum and Assessment, Conway (2013, 52-53) contextualises the bleak situation in Ireland at this time and how this paved the way for significant reform:

First, the country experienced a traumatic economic downturn in 2008-2010, leading to a bailout by the International Monetary Fund and the European Central Bank (hereafter 'IMF/ECB bailout') in December 2010. Second, in November 2010, the PISA 2009 results indicated that scores for Ireland's 15 -year-olds in reading literacy had dropped more than any other country, and the reading literacy ranking had dropped from fifth in 2000 to 21 st in 2009 among the 65 participating countries (17th of 34 participating OECD countries). Third, following the IMF/ECB bailout, an election in spring 2011 led to the appointment of a reform-oriented Minister for Education and Skills.

The arrival of 'a reform-orientated Minister for Education and Skills', Ruairí Quinn, at this time brought with it significant changes in Irish education, including, inter alia, the introduction of a national strategy for improving literacy and numeracy; the reform and extension of Initial Teacher Education programmes; and new modes of school 
inspections, including the compulsory requirement for schools to engage in school selfevaluation. As Brown et al. (2018) point out, Ireland's 'PISA shock' in 2010 required school self-evaluations to focus on literacy, numeracy or an aspect of teaching and learning (Brown et al. 2018). School self-evaluation however, as Brady (2016) points out, is specifically focused on the rhetoric of greater school autonomy, and as we have argued elsewhere, often the rhetoric of autonomy is very much that - rhetorical and mythical (Skerritt 2019e; Salokangas and Ainscow 2017). As Verger and Parcerisa $(2019,146)$ highlight about current education reform packages,

school autonomy and accountability tend to be conceived as inseparable. This is due to the fact that governments in their role as principal should be willing to give more autonomy to schools in organisational, budgetary and/or curricular terms, to the extent that schools accept stricter supervision and control via external evaluation and related accountability measures.

In addition to the introduction of standardised testing (Brown, McNamara, and O'Hara 2016a) in Ireland, new models of risk-based inspections (Brown et al. 2016b) such as incidental/unannounced inspections have seen state inspectors assume new roles as the as sole arbiters of 'good teaching' (Mooney Simmie, Moles, and O'Grady 2019). What we are witnessing is a change in the relations of power between teachers and the state (Ball 2016). The rising accountability in Irish education seemingly still entrenches a responsive regulatory framework and there is a concern that sanctions and punitive measures may act as a mechanism for marketisation, corporatisation and, ultimately, privatisation (Carr and Beckett 2018). With education in Ireland coming to be more closely linked to economic growth and global competitiveness, particularly given Ireland's economic climate over the last decade, calls to more closely align educational practices to the needs of businesses and employers may on the surface appear to be justified (Ó Breacháin and O’Toole 2013) and it appears that the state's intention, as is evident in, for example, curriculum reform, has been to propel its publicly aided schools into a competitive survival-of-the-fittest market (Mooney Simmie 2014).

\section{Concluding remarks}

As our analysis has shown, the role of the private sector in Irish public education is historically considerable. While the pressures to cater to an increasingly secularised society are growing, if changes were to occur, it is likely that they would be slow. Even if there was political will for the state to 'take over' or 'deprivatise' schools which operate under religious patronage, it would be a costly and controversial endeavour and therefore highly unlikely. This is partly because in most cases the church owns the school buildings and the land, and in the current economic circumstances it is unimaginable that the state finances would stretch to taking over buildings and sites. However, in light of rapid secularisation of the civil state the question of patronage and church involvement requires solving. As the system stands, especially the primary sector with over 90 percent of schools being run by religious patrons, it simply does not reflect the population it serves. Time will tell whether the state's continuous proposals concerning increased school autonomy and new forms of privatisation, combined with the welcoming of new private actors to the education arena, will serve as a 'solution' to the patronage question. We argue here that the pathway to an 
increase of privatisation in Ireland is possible, has historical precedent, and in some senses the ground is being cleared to enable it to happen.

Verger, Fontdevila, and Zancajo's (2017) conceptualisation has offered helpful tools for demonstrating privatisation processes and relationships between the public and private in Irish education. However, the early childhood education and care (ECEC) sector is missing from our analysis. The ECEC sector in Ireland is a fully privatised model, having been neglected by policy makers for decades (Hayes 2016). Only recently the state has taken steps in bringing cohesion and steering to this sporadic sector through, for example, the introduction of a free pre-school year (Hayes 2016). It is beyond the scope of this article to examine these developments in depth, but it is worth pointing out that ECEC in Ireland makes a somewhat uncomfortable example of public and private interplay in education as it does not resonate with the existing conceptual categories put forward in CPE. Further conceptual work is perhaps needed in order to acknowledge such 'reverse' privatisation processes involving notions of 'deprivatisation' and growing state involvement.

Finally, and in line with Verger, Fontdevila, and Zancajo (2017), we argue that it is important to focus on the interaction between global drivers and more locally situated factors and contingencies in order to develop a more comprehensive understanding of local reforms in education. Therefore, in order for us to better understand these processes in Ireland, future research locating Ireland more explicitly to global developments is paramount. Comparative perspectives including countries that also feature strong historical public-private partnerships, whilst having taken a neoliberal turn in policy, such as Spain and Belgium, could provide fruitful points of comparison.

\section{Disclosure statement}

No potential conflict of interest was reported by the authors.

\section{Notes on contributors}

Craig Skerritt is a researcher at the Centre for Evaluation, Quality and Inspection, Dublin City University. His research interests include education policy and governance, school evaluation and inspection, and the impact of change on teacher identity. His work has been published in journals such as Research Papers in Education, Irish Educational Studies, and Improving Schools. Craig is also the Policy and International Programmes Manager at the Royal Irish Academy and a member of the British Educational Research Association and the Educational Studies Association of Ireland.

Maija Salokangas is an assistant professor at the School of Education, Trinity College Dublin. Her recent book Inside the Autonomous School: Making Sense of a Global Educational Trend (with Mel Ainscow) critiques the school autonomy movement and associated privatisation processes. Her current research examines teacher autonomy in Ireland, Finland, Germany and Sweden.

\section{ORCID}

Craig Skerritt (D) http://orcid.org/0000-0002-3695-758X

\section{References}

Akenson, Donald. 2012. A Mirror to Kathleen's Face: Education in Independent Ireland 1922-60. New York: Routledge. 
Ball, Stephen J. 2016. "Neoliberal Education? Confronting the Slouching Beast." Policy Futures in Education 14 (8): 1046-1059.

Ball, Stephen J. 2018. "Commericalising Education: Profiting from Reform!.” Journal of Education Policy 33 (5): 587-589.

Ball, Stephen J., and Deborah Youdell. 2007. Hidden Privatisation in Public Education (preliminary report). Brussels: Education International 5th World Congress.

Baxter, Jacqueline. 2017. "School Inspectors as Policy Implementers: Influences and Activities." In School Inspectors: Policy Implementers, Policy Shapers in National Policy Contexts, edited by Jacqueline Baxter, 1-23. London: Springer.

Brady, Alison M. 2016. “The Regime of Self-Evaluation: Self-Conception for Teachers and Schools.” British Journal of Educational Studies 64 (4): 523-541.

Brown, Martin, Gerry McNamara, and Joe O’Hara. 2016a. "Quality and the Rise of Value-Added in Education: The Case of Ireland.” Policy Futures in Education 14 (6): 810-829.

Brown, Martin, Gerry McNamara, Joe O’Hara, and Shivaun O’Brien. 2016b. "Exploring the Changing Face of School Inspections." Eurasian Journal of Educational Research 66: 1-26.

Brown, Martin, Gerry McNamara, Joe O'Hara, Shivaun O’Brien, Jerich Faddar, and Cornelius Young. 2018. "Integrated Co-Professional Evaluation? Converging Approaches to School Evaluation across Frontiers." Australian Journal of Teacher Education 43 (12): 76-90.

Byrne, Richard, and Dympna Devine. 2018. "'Catholic Schooling with a Twist?': A Study of Faith Schooling in the Republic of Ireland During a Period of Detraditionalisation." Cambridge Journal of Education 48 (4): 461-477.

Canny, Angela, and Miriam Hamilton. 2018. "A State Examination System and Perpetuation of Middle-Class Advantage: An Irish School Context.” British Journal of Sociology of Education 39 (5): 638-653.

Carr, John, and Lori Beckett. 2018. Teachers and Teacher Unions in a Globalised World: History, Theory and Policy in Ireland. Oxon: Routledge.

Carrasco, Alejandro, and Helen M. Gunter. 2019. "The 'Private' in the Privatisation of Schools: The Case of Chile." Educational Review 71 (1): 67-80.

Cole, Alistair, and Glen Jones. 2005. "Reshaping the State: Administrative Reform and New Public Management in France." Governance 18 (4): 567-588.

Conway, Paul F. 2013. "Cultural Flashpoint: The Politics of Teacher Education Reform in Ireland." The Educational Forum 77 (1): 51-72.

Conway, Paul F., and Rosaleen Murphy. 2013. "A Rising Tide Meets a Perfect Storm: New Accountabilities in Teaching and Teacher Education in Ireland." Irish Educational Studies 32 (1): 11-36.

Coolahan, John, Sheelagh Drudy, Padraig Hogan, and Seamus McGuiness. 2017. Towards A Better Future:A Review of the Irish School System. Cork: Irish Primary Principals' Network and the National Association of Principals and Deputy Principals.

Courtney, Steven J. 2015. "Corporatised Leadership in English Schools." Journal of Educational Administration and History 47 (3): 214-231.

Darmody, Merike, and Emer Smyth. 2018. "Religion and Primary School Choice in Ireland: School Institutional Identities and Student Profile.” Irish Educational Studies 37 (1): 1-17.

Department of Education and Skills. 2015a. Advancing School Autonomy in the Irish School System: Research Paper. Dublin: Department of Education and Skills.

Department of Education and Skills. 2015b. Advancing School Autonomy in the Irish School System: Consultation Paper. Dublin: Department of Education and Skills.

Department of Education and Skills. 2016. Action Plan for Education 2016-2019. Dublin: Department of Education and Skills.

Department of Education and Skills. 2017. Action Plan for Education 2017. Dublin: Department of Education and Skills.

Dolan, Anne M. 2012. "Reforming Teacher Education in the Context of Lifelong Learning: The Case of the BEd Degree Programme in Ireland." European Journal of Teacher Education 35 (4): 463-479. 
Drudy, Sheelagh. 2009. "Education and the Knowledge Economy: A Challenge for Ireland in Changing Times." In Education in Ireland: Challenge and Change, edited by Sheelagh Drudy, 35-53. Dublin: Gill and Macmillan.

Drudy, Sheelagh, and Kathleen Martha Lynch. 1993. Schools and Society in Ireland. Dublin: Gill \& Macmillan.

Faas, Daniel, Merike Darmody, and Beata Sokolowska. 2016. "Religious Diversity in Primary Schools: Reflections from the Republic of Ireland." British Journal of Religious Education 38 (1): 83-98.

Faas, Daniel, Aimee Smith, and Merike Darmody. 2018. "Children's Agency in Multi-Belief Settings: The Case of Community National Schools in Ireland." Journal of Research in Childhood Education 32 (4): 486-500.

Flanagan, Kieran. 1984. “The Shaping of Irish Anglican Secondary Schools, 1854-1878." History of Education 13 (1): 27-43.

Fleming, Brian. 2016. Irish Education 1922-2007: Cherishing All the Children? CreateSpaceIndependent Publishing Platform.

Fleming, Brian, and Judith Harford. 2014. "Irish Educational Policy in the 1960s: A Decade of Transformation.” History of Education 43 (5): 635-656.

Fuller, Kay, and Howard Stevenson. 2019. "Global Education Reform: Understanding the Movement." Educational Review 71 (1): 1-4.

Furlong, Catherine. 2013. "The Teacher I Wish to Be: Exploring the Influence of Life Histories on Student Teacher Idealised Identities.” European Journal of Teacher Education 36 (1): 68-83.

Government of Ireland. 2018. Action Plan for Education 2018. Dublin: Government of Ireland.

Gruening, Gernod. 2001. “Origin and Theoretical Basis of New Public Management.” International Public Management Journal 4 (1): 1-25.

Hall, Kathy, and Mary Horgan. 2015. "Introduction to the Special Issue: Contemporary Irish Education.” International Electronic Journal of Elementary Education 8 (2): 175-178.

Harford, Judith. 2010. "Teacher Education Policy in Ireland and the Challenges of the Twenty-First Century." European Journal of Teacher Education 33 (4): 349-360.

Hayes, Noirin. 2016. "Early Childhood Education and Care: A Neglected Policy Arena?" In The Irish Welfare State in the Twenty-First Century, edited by Mary P. Murphy and Fiona Dukelow, 193-214. London: Palgrave Macmillan.

Higgins, Sean, and Mario Novelli. 2018. "The Potential and Pitfalls of Peace Education: A Cultural Political Economy Analysis of the Emerging Issues Teacher Education Curriculum in Sierra Leone." Asian Journal of Peacebuilding 6 (1): 29-53.

Hislop, H. 2012. The Quality Assurance of Irish Schools and the Role of Evaluation: Current and Future Trends: The Professor Seamas Ó Súilleabháin Memorial Lecture. Maynooth: National University of Ireland Maynooth.

Holland, Charlotte, Francsesa Lorenzi, and Tony Hall. 2016. "Performance Anxiety in Academia: Tensions Within Research Assessment Exercises in an Age of Austerity." Policy Futures in Education 14 (8): 1101-1116.

Holloway, Jessica, and Amanda Keddie. 2018. “Make Money, Get Money’: How Two Autonomous Schools Have Commercialised Their Services.” Discourse: Studies in the Cultural Politics of Education 1-13. https://www.tandfonline.com/doi/abs/10.1080/01596306.2018.1451305.

Hood, Christopher. 1995. “The 'New Public Management' in the 1980s: Variations on a Theme.” Accounting, Organizations and Society 20 (2-3): 93-109.

Houtsonen, Jarmo, Magdalena Czaplicka, Sverker Lindblad, Peter Sohlberg, and Ciaran Sugrue. 2010. "Welfare State Restructuring in Education and Its National Refractions: Finnish, Irish and Swedish Teachers' Perceptions of Current Changes." Current Sociology 58 (4): 597-622.

The Irish Times. 2011. The 50 Most Influential People in Education. https://www.irishtimes.com/ news/the-50-most-influential-people-in-education-1.613561.

Jessop, Bob. 2007. "New Labour or the Normalization of Neo-Liberalism?" British Politics 2 (2): 282-288.

Jessop, Bob. 2010. "Cultural Political Economy and Critical Policy Studies." Critical Policy Studies 3 (3-4): 336-356. 
Kauko, Jaakko, and Maija Salokangas. 2015. "The Evaluation and Steering of English Academy Schools Through Inspection and Examinations: National Visions and Local Practices." British Educational Research Journal 41 (6): 1108-1124.

King, Fiona, Christine Forde, Jamila Razzaq, and Deirdre Torrance. 2019. "Systems of Education Governance and Cultures of Justice in Ireland, Scotland and Pakistan.” In Cultures of Social Justice Leadership: An Intercultural Context of Schools, edited by Pamela S. Angelle and Deirdre Torrance, 67-92. Cham: Palgrave Macmillan.

Kitching, Karl. 2014. The Politics of Compulsive Education: Racism and Learner-Citizenship. Oxon: Routledge.

Liddy, Mags, Joanne O’Flaherty, and Orla McCormack. 2019. “'The Million-Dollar Question'Exploring Teachers and ETB Staff Understanding of Characteristic Spirit in Publicly Managed Schools in Ireland." Irish Educational Studies 38 (1): 105-119.

Lynch, Kathleen. 2012. "On the Market: Neoliberalism and New Managerialism in Irish Education." Social Justice Series 12 (5): 88-102.

Lynch, Kathleen, and Marie Moran. 2006. "Markets, Schools and the Convertibility of Economic Capital: The Complex Dynamics of Class Choice." British Journal of Sociology of Education 27 (2): 221-235.

MacVeigh, Tina. 2012. “Can a Meritocratic Education System Deliver Equality?" Irish Marxist Review 1 (4): 27-36.

McCormack, O., J. O'Flaherty, B. O’Reilly, and J. Liston. 2019. “That's How It Works Here': The Place of Religion in Publicly Managed Second-Level Schools in Ireland.” British Educational Research Journal 45 (1): 161-180.

Mooney Simmie, Geraldine. 2012. "The Pied Piper of Neo Liberalism Calls the Tune in the Republic of Ireland: An Analysis of Education Policy Text from 2000-2012." Journal for Critical Education Policy Studies 10 (2): 485-514.

Mooney Simmie, Geraldine. 2014. “The Neo-Liberal Turn in Understanding Teachers' and School Leaders' Work Practices in Curriculum Innovation and Change: A Critical Discourse Analysis of a Newly Proposed Reform Policy in Lower Secondary Education in the Republic of Ireland." Citizenship, Social and Economics Education 13 (3): 185-198.

Mooney Simmie, Geraldine, Joanne Moles, and Emmanuel O'Grady. 2019. "Good Teaching as a Messy Narrative of Change Within a Policy Ensemble of Networks, Superstructures and Flows." Critical Studies in Education 60 (1): 55-72.

Murphy, Timothy. 2008. "Democratic Schooling Practices in the Republic of Ireland: The Gaps Between the Rhetoric and Reality." Irish Educational Studies 27 (1): 29-39.

Murphy, Gavin. 2019. "A Tangled Tale? Teachers Making Sense of School Evaluation in the Republic of Ireland." In School Evaluation with a Purpose, edited by Eli Ottesen and Fiona Stephens, 53-66. Oxon: Routledge.

Noblet, Andrew J., and John J. Rodwell. 2009. "Identifying the Predictors of Employee Health and Satisfaction in an NPM Environment: Testing a Comprehensive and Non-Linear DemandControl-Support Model.” Public Management Review 11 (5): 663-683.

Ó Breacháin, Annie, and Leah O’Toole. 2013. "Pedagogy or Politics?: Cyclical Trends in Literacy and Numeracy in Ireland and Beyond." Irish Educational Studies 32 (4): 401-419.

Ó Buachalla, Seamas. 1985. "Church and State in Irish Education in This Century." European Journal of Education 20 (4): 351-359.

O’Doherty, Teresa, and Judith Harford. 2018. "Teacher Recruitment: Reflections from Ireland on the Current Crisis in Teacher Supply." European Journal of Teacher Education 41 (5): 654-669.

O'Donoghue, Tom, and Judith Harford. 2011. “A Comparative History of Church-State Relationsin Irish Education." Comparative Education Review 55 (3): 315-341.

O’Donoghue, Tom, Judith Harford, and Teresa O'Doherty. 2017. Teacher Preparation in Ireland: History, Policy and Future Directions (Emerald Studies in Teacher Preparation in National and Global Contexts). Bingley: Emerald Publishing Limited. 
O’Flaherty, Joanne, Orla McCormack, Jim Gleeson, B. O’Reilly, E. O'Grady, and N. Kenny. 2018. "Developing the Characteristic Spirit of Publicly Managed Schools in a More Secular and Pluralist Ireland." Cambridge Journal of Education 48 (3): 317-333.

Patrick, Clancy. 2005. "Education Policy.” In Contemporary Irish Social Policy, edited by Suzanne Quinn, Patricia Kennedy, Anne Matthews, and Gabriel Kiely, 80-114. Dublin: University College Dublin Press.

Paudel, Mohan. 2013. "Is There New Public Health Management (NPM) in Nepal? Arguments for and Against NPM in Nepal." Social Work in Public Health 28 (7): 702-712.

Quinn, Ruairi. 2012. “The Future Development of Education in Ireland.” Studies: An Irish Quarterly Review 101 (402): 123-138.

Robertson, Susan L., and Roger Dale. 2015. “Towards a 'Critical Cultural Political Economy' Account of the Globalising of Education." Globalisation, Societies and Education 13 (1): 149-170.

Rougier, Nathalie, and Iseult Honohan. 2015. "Religion and Education in Ireland: Growing Diversity - or Losing Faith in the System?” Comparative Education 51 (1): 71-86.

Sahlberg, Pasi. 2011. “The Fourth Way of Finland.” Journal of Educational Change 12 (2): 173-185. Sahlberg, Pasi. 2015. Finnish Lessons 2.0: What Can the World Learn from Educational Change in Finland? New York: Teachers College Press.

Sai, Youcef. 2018. “'I Can't Cope Seeing my Kids ... Hearing These Kinds of Prayers.' Parents' Rationale for Choosing State-Funded Muslim Schools in the Republic of Ireland: An Ethnographic Study." Journal of Contemporary Religion 33 (3): 549-565.

Salokangas, Maija, and Mel Ainscow. 2017. Inside the Autonomous School: Making Sense of a Global Educational Trend. Oxon: Routledge.

Salokangas, Maija, and Christopher Chapman. 2014. "Exploring Governance in two Chains of Academy Schools: A Comparative Case Study." Educational Management Administration \& Leadership 42 (3): 372-386.

Sellar, Sam, and Bob Lingard. 2013. “The OECD and Global Governance in Education.” Journal of Education Policy 28 (5): 710-725.

Skerritt, Craig. 2019a. “Irish Migrant Teachers' Experiences and Perceptions of Autonomy and Accountability in the English Education System." Research Papers in Education 34 (5): 569-596.

Skerritt, Craig. 2019b. "Privatization and 'Destatization': School Autonomy as the 'Anglo Neoliberalization’ of Irish Education Policy.” Irish Educational Studies 38 (2): 263-279.

Skerritt, Craig. 2019c. "Discourse and Teacher Identity in Business-Like Education." Policy Futures in Education 17 (2): 153-171.

Skerritt, Craig. 2019d. “I Think Irish Schools Need to Keep Doing What They're Doing': Irish Teachers' Views on School Autonomy after Working in English Academies." Improving Schools 22 (3): 267-287.

Skerritt, Craig. 2019e. "Inside the Autonomous School: Making Sense of a Global Educational Trend." British Journal of Educational Studies 67 (3): 417-420.

Smyth, Emer. 2008. "The More, the Better? Intensity of Involvement in Private Tuition and Examination Performance." Educational Research and Evaluation 14 (5): 465-476.

Smyth, Emer. 2009. "Buying Your Way Into College? Private Tuition and the Transition to Higher Education in Ireland.” Oxford Review of Education 35 (1): 1-22.

Stapleton, Catherine. 2018. "An Exploration of the Experiences of Minority Faith and Minority Worldview Students of a Roman Catholic School Ethos in Post-Primary Schools in the Republic of Ireland." Doctoral thesis, Dublin City University, Dublin.

Steane, Peter, Yvonne Dufour, and Donald Gates. 2015. "Assessing Impediments to NPM Change." Journal of Organizational Change Management 28 (2): 263-270.

Sugrue, Ciaran. 2006. "A Critical Appraisal of the Impact of International Agencies on Educational Reforms and Teachers' Lives and Work: The Case of Ireland?" European Educational Research Journal 5 (3-4): 181-195.

Verger, Antoni, and Marta Curran. 2014. "New Public Management as a Global Education Policy: Its Adoption and Re-Contextualization in a Southern European Setting." Critical Studies in Education 55 (3): 253-271. 
Verger, Antoni, Clara Fontdevila, and Lluis Parcerisa. 2019a. "Reforming Governance Through Policy Instruments: How and to What Extent Standards, Tests and Accountability in Education Spread Worldwide." Discourse: Studies in the Cultural Politics of Education 40 (2): 248-270.

Verger, Antoni, Clara Fontdevila, and Adrian Zancajo. 2016. The Privatization of Education: A Political Economy of Global Education Reform. New York: Teachers College Press.

Verger, Antoni, Clara Fontdevila, and Adrian Zancajo. 2017. "Multiple Paths Towards Education Privatization in a Globalizing World: A Cultural Political Economy Review." Journal of Education Policy 32 (6): 757-787.

Verger, Antoni, Mauro Moschetti, and Clara Fontdevila. 2018. “The Expansion of Private Schooling in Latin America: Multiple Manifestations and Trajectories of a Global Education Reform Movement." In The Wiley Handbook of Global Educational Reform, edited by Kenneth Saltman and Alexander Means, 131-155. New Jersey: Wiley Blackwell.

Verger, Antoni, and Lluis Parcerisa. 2019. "Test-Based Accountability and the Rise of Regulatory Governance in Education: A Review of Global Drivers." In Education Governance and Social Theory: Interdisciplinary Approaches to Research, edited by Andrew Wilkins and Antonio Olmedo, 139-158. London: Bloomsbury.

Verger, Antoni, Lluis Parcerisa, and Clara Fontdevila. 2019b. "The Growth and Spread of LargeScale Assessments and Test-Based Accountabilities: A Political Sociology of Global Education Reforms.” Educational Review 71 (1): 5-30.

Visser, Max, Roel Schouteten, and Josje Dikkers. 2019. "Controlling the Courts: New Public Management and the Dutch Judiciary.” Justice System Journal 40 (1): 39-53.

Wallis, Joe L., and Brian E. Dollery. 1999. "Understanding the Rhetorical Patterns that Emerge During a Process of Paradigmatic Policy Change: The Case of New Public Management." International Review of Public Administration 4 (2): 57-66.

Walsh, John. 2008. "Have the Snakes Come Back?: The Family and the Defence of Catholic Educational Structures in Ireland (1957-1975)." The History of the Family 13 (4): 416-425.

Walshe, John. 1999. A New Partnership in Education: From Consultation to Legislation in the Nineties. Dublin: Institute of Public Administration.

Winchip, Emily, Howard Stevenson, and Alison Milner. 2019. "Measuring Privatisation in Education: Methodological Challenges and Possibilities." Educational Review 71 (1): 81-100. 